\title{
MENEGAKKAN EVOLUSI PERADABAN BANGSA
}

\author{
Bustami Rahman*
}

\begin{abstract}
Although Indonesia suffered from European colonization like most of East Asian countries in the past, its civilizational characteristic is distinct from that of its closest neighbors such as Malaysia, Singapore, and Brunei Darussalam. As a nation, Indonesia is poorer in terms of discipline, law enforcement, and economy. This writing proposes a hypothesis that the cause of such distinction is not the different colonizers. Instead, it is Indonesia's attitude towards its colonizer that makes it different. In a sense, Malaysia, Singapore, and Brunei Darussalam were "given" freedom by the British Empire, while Indonesia obtained its freedom by force, followed by the removal of all traces of its colonizer, which include the old European values. It was reborn and began its new life as a baby, experiencing multiple dying dots and faltered several times. To survive, Indonesia began its complicated, vicious cycle of involution while its neighbors began their evolution. There are three things that must be done to stop the cycle and enforce an evolutive Indonesian civilization. First, the leaders of this country should learn the reason behind the current poor condition of Indonesia, so they can restrain themselves from making the wrong moves. Second, the implementation of the system should be more repressive at certain times, to enforce discipline and law. Third, it is important to learn that democracy can come in many colors since all nations have different natures and needs.
\end{abstract}

Keywords :

Evolution and Civilizational of Nation

\section{Proses Perwujudan Diri Bangsa}

\section{Indonesia}

Perwujudan diri suatu bangsa di manapun di dunia ini senantiasa melalui proses pertumbuhan peradabannya masingmasing. Peradaban itu sendiri memiliki unsur-unsur yang baku yang telah sekian lama ditunjukkan dalam kajian-kajian sosial kelas dunia, seperti nilai-nilai yang terbangun dari aspek-aspek kehidupan ekonomi, politik, religi, budaya umum, ,

*Penulis adalah Guru Besar Sosiologi dan pengajar pada Jurusan Sosiologi, Fakultas Ilmu Sosial dan Ilmu Politik, Universitas Bangka Belitung. ilmu pengetahuan, teknologi, dan seni. Nilai-nilai yang terus berkembang dan juga berubah itu memiliki hukum dinamika dan mekanismenya sendiri, sehingga pada suatu saat (yang batasnya sangat kualitatif) mewujudkan bentukan peradaban dengan sifat-sifatnya yang umum dimiliki oleh setiap bangsa dari tipologi sistem sosial budaya yang berbeda. Sistem yang terbentuk dari proses demikian itu akan mencerminkan adanya karakter dari suatu sistem yang bersifat umum pula, yakni sebagaimana kita kenal sifat-sifatnya: saling berketergantungan (interdependently), beraturan (orderly), 
dan cenderung untuk bertahan (durably). Jika dasar pemikiran teoretisnya demikian, maka apakah sistem atau struktur sosial budaya bangsa Indonesia itu telah terwujud, dan apakah saat ini bangsa Indonesia sedang berkembang di dalam suatu sistem sosial budaya yang telah 'menjadi', atau dalam proses di jalan yang 'benar' atau sebaliknya sedang berada di jalan yang 'salah'. Pertanyaan ini sangat mendasar dan krusial untuk segera dicari jawabannya.

Pearadaban bangsa Indonesia sebagai suatu bangsa, yang dalam kerangka Negara Kesatuan Republik Indonesia adalah benar-benar masih sangat muda. Dirunut agak jauh ke belakang pun, terlepas dari persyaratan geografi politik, Indonesia Nusantara dalam makna kultural, peradabannya juga masih terlalu muda. Apalagi jika dibandingkan dengan peradaban belahan dunia lain seperti Afrika, Eropa (Eurosia), India, Mesir, China dan Korea, Yunani dan Persia yang telah bermula sejak 3000-500 SM. (Untuk mendalami peradaban 'the Old World and New World', bisa dibaca antara lain: Crane Brinton, 1984; Guy Ankerl, 2000; Jane Crisholm and Anne Millard, 1991; Flipe Armesto Fernandes, 2000; Andrey Korotayev, 2004; dan A. Nuri Yurdusev, 2003).

Dalam usia yang masih sangat muda itu sebenarnya orang bisa berdalih untuk mengatakan bahwa peradaban
Indonesia sekarang yang dipertanyakan itu wajar saja terwujud demikian. Disiplin yang rendah, penegakan hukum yang lemah, dan mudah jatuh dalam dilema. Akibatnya penyimpangan terhadap tata nilai mudah terjadi, mudah kehilangan arah dan kontrol diri. Selain itu terjadi juga anomie karena adanya gap antara nilainilai yang berkembang di dalam tataran individu dengan nilai-nilai yang berkembang di dalam tataran sistem atau stuktur sosial budayanya. Di dalam struktur atau sistem sosial budaya yang nilai-nilainya dipandang tidak jelas oleh aktor sosialnya (bukan karena hanya tidak jelas aturan tertulisnya, tetapi yang lebih parah jika tidak jelas dalam pelaksanaannya), maka sang aktor tidak akan mampu membedakan norma mana yang salah dan norma mana yang benar.

Akan tetapi, tidak boleh disimpan dan dikembangkan suatu dalih bahwa peradaban yang muda itu tadi menjadi alasan untuk menjawab mengapa bangsa ini kedodoran di dalam melakukan proses peradabannya selama ini. Bukti menunjukkan bahwa bangsa-bangsa (dalam makna geografi politik atau kultural) yang muda belia, seperti Singapura, Malaysia, Brunei Darussalam mampu menegakkan peradaban mereka searah dan selaju dengan arah dan laju peradaban bangsa-bangsa dunia yang lebih tua. Pertanyaan berikutnya, mengapa mekanisme itu tidak terjadi di dalam diri 
bangsa Indonesia. Jangan diharapkan bahwa tulisan ini akan semata-mata mencari dan menyalahkan siapa yang bertanggungjawab, karena semuanya itu tidak akan menjawab persoalan yang sebenarnya. Pemerintah, bahkan budaya hanyalah produk masa lalu. Tulisan ini akan menelusuri rentetan masa lalu itu di kala bangsa Indonesia sedang dan akan melakukan upaya yang sadar meraih kemerdekaannya untuk melepaskan diri dari kungkungan penjajah bangsa lain. Analisis Sosiologi Sejarah akan sangat berguna sebagai pisau analisis untuk mengungkapkan jawaban atas pertanyaan itu tadi.

\section{Peradaban yang Terputus-Putus}

Bangsa Indonesia dalam makna cultural (sebelum Indonesia Merdeka dan sebelum terbentuknya Negara Kesatuan), dan dalam makna geografi politik (sesudah kemerdekaan dan sesudah terbentuknya Negara Kesatuan), telah terlalu sering mengalami 'titik-titik sekarat' (dying dots)dalam hidupnya. 'Titik-titik sekarat' yang sangat berpengaruh adalah yang terjadi pada saat bangsa ini merebut kemerdekaan dan pada masa beberapa puluh tahun pascakemerdekaan. Jika bangsa ini tidak waspada dan tidak berhatihati, maka bahkan ada kemungkinan terjadi juga pada masa-masa sekarang dan akan datang. 'Titik-titik sekarat' pada masa prakemerdekaan juga tidak kalah frekuensi terjadinya, seperti perang antar atau intra kerajaan, perang suku, perang kerajaan dengan suku, perang kerajaan dengan para pemberontak, dan lain sebagainya. Namun, semuanya itu telah berlalu dan bangsa Indonesia telah memulainya di tahun 1945 hampir-hampir dari titik zero. 'Titik sekarat' pada masa prakemerdekaan yang paling krusial pengaruhnya terhadap proses peradaban bangsa Indonesia selanjutnya adalah perang kemerdekaan.

Perang kemerdekaan adalah momen politik yang paling diagungkan dalam kerangka liberasi untu untuk mewujudkan suatu bangsa baru dengan ideologi dan idealisme baru. Pembebasan diri secara politik itu ternyata juga adalah sekaligus pembebasan diri dari ideologi dan nilai-nilai lama yang selama ini telah dibelitkan oleh penjajah ke batang tubuh anak bangsa ini. Dengan perkataan lain, nilai-nilai dalam peradaban lama yang dikenalkan oleh penjajah melalui pemerintahan negara penjajah ratusan tahun sebelumnya, dalam sekejap diurai dan dilepas dengan perasaan dan sikap resistensi yang luar biasa hebatnya. Dalam situasi demikian itu, nilai-nilai lama dicampakkan dan nilai-nilai baru diupayakan untuk dihimpun kembali melalui kecerdasan lokal anak-anak bangsa pada masa itu. 
Pencampakan nilai-nilai lama dalam suatu system beamsendstadt dan mencoba suatu nilai yang berbeda merupakan momen yang luput diperhatikan dalam kajian sejarah dan politik bangsa ini. Padahal, momen ini sangatlah pentingnya untuk menjelaskan mengapa proses peradaban bangsa kita berbeda dari proses peradaban bangsabangsa lain di sekitar kita. Hipotesis ini mengatakan bahwa terputusnya peradaban di tahun 1945 dari akar peradaban Eropa yang diwakili oleh Belanda telah mengakibatkan kita kehilangan konteks peradaban Eropa,di mana Belanda merupakan salah satu bangsa perwakilan peradaban 'dunia lama' (the old world). Terlepas dari sentimen atau romantisme kebangsaan ataupun romatisme agama (karena kedua terakhir yang saya sebutkan ini tidak sama sekali berkorelasi dengan peradaban yang baik atau yang tidak baik dalam persepsi umum), peradaban Eropa secara faktual telah mampu mengesankan beberapa aspek keunggulan dalam pencapaiannya. Kemajuan dalam bidang sains dan teknologi, ketertiban hukum, disiplin, tingkat kesejahteraan ekonomi, stabilitas politik dan keamanan merupakan bukti-bukti yang mengesankan keunggulan peradaban mereka. Secara lebih adil ingin dinyatakan di sini apa yang dianggap merupakan sisi gelap dari peradaban mereka di bidang kebebasan moral, bagi pengamat moral mungkin akan membawa mereka kepada kegelapan dan kehancuran Barat di masa-masa yang akan datang.

Terlepas dari pandangan demikian, marilah konsentrasi pada hipotesis yang dibangun di atas tadi. Terputusnya peradaban akibat titik sekarat perang kemerdekaan, yakni mencampakkan nilai peradaban lama dan menggantikannya dengan nilai peradaban baru yang sama sekali berbeda akan mengakibatkan terputusnya rantai peradaban. Padahal, suatu peradaban adalah proses panjang tanpa henti yang merupakan garis kontinum yang tidak diketahui kapan akan berakhir. Sebenarnya tidak ada yang melarang suatu bangsa untuk membuang jauh-jauh nilai peradaban lama dan menggantikannya dengan yang baru, sebagaimana tidak ada orang yang dapat menjamin suatu bangsa dapat terus menerus mempertahankan peradaban yang mereka sukai untuk selama-lamanya. Ada momen di mana suatu bangsa terpaksa harus melakukan sesuatu, yang jika tidak dilakukan demikian maka eksistensi suatu bangsa itu akan terancam selamanya. Kebanggaan diri, harga diri, nasionalisme, dan liberasi merupakan hak paling wahid dari suatu bangsa. Akan tetapi, semua itu bukanlah komteks utama hipotesis ini. Konteks pentingnya adalah bahwa pada tahun 1945 telah terjadi pemutusan rantai peradaban, yang mungkin sekali dampak sosial budaya dan politiknya tidak pernah terbayangkan sebelumnya. 


\section{Kasus Bangsa Sekitar}

Pada kasus Malaysia, Singapura, dan juga Brunei Darussalam yang mengalami penjajahan peradaban Eropa, yakni Inggeris dengan sedikit sentuhan Jepang (Wikipedia, 2008; Infoplease, 2008) menunjukkan gejala yang berbeda. Pertumbuhan peradaban mereka lebih stabil, karena nilai-nilai peradaban yang dikembangkan jelas sekali merupakan sustainabilitas dari garis kontinum peradaban Eropa yang telah bercokol di kawasan itu ratusan tahun. Sampai di sini mungkin ada celah bagi pertanyaan kritis, tetapi mudah untuk dipatahkan. Apakah karena sistem pemerintahan dengan gaya (style) Inggeris berbeda dari system pemerintahan gaya Belanda? Konon Inggeris lebih bergaya akomodatif, manakala Belanda lebih bergaya eksploitatif? Tentu saja pertanyaan agak beraroma romantisme sejarah ini kurang beralasan, karena semua penjajahan di muka bumi pada era abad 18-19 tidak akan lepas dari sifatnya yang eksploitatif. Sedikit upaya yang lebih lunak yang dilakukan oleh masing-masing pihak penjajah hanyalah sekedar melakukan politik 'balas budi' dan tidak mampu menghapus kesan dan citra penjajah sebagai ekstorsionis.

Oleh karena itu, hipotesis ini menempatkan Belanda dan Inggeris dalam kelas dan bobot yang sama dalam kerangka memberi pengaruh peradaban
Eropa terhadap Indonesia di satu pihak dan terhadap bangsa Malaysia, Singapura, dan Brunei Darussalam di pihak yang lain. Ada beberapa bangsa lain yang perlu disebut dalam uraian ini sebagai contoh kasus penguat hipotesis, yakni Vietnam yang juga mengalami pemutusan rantai peradaban Eropa (Prancis) dan kemudian sedikit pengaruh Amerika yang kurang berbekas (Infoplease, 2008). Pola proses pertumbuhan peradaban mereka mendekati pola proses pertumbuhan peradaban Indonesia. Kemudian yang perlu disebut lagi adalah Thailand yang sangat minim sentuhan peradaban Eropa, karena hampir tidak mengalami penjajahan fisik sebagaimana dialami oleh tetangga mereka yang lain, kecuali persentuhan dalam makna kultural, sains dan teknologi (Wikipedia, 2008). Di bawah ini kita perlu memperoleh penjelasan lanjut. Pertama, bagaimana pengaruh peradaban penjajah tersebut terhadap bangsa yang dijajah dengan resistensi minimal (kasus Malaysia, Singapura dan Brunei), dan kedua, bagaimana pengaruh peradaban penjajah tersebut terhadap bangsa yang dijajah dengan resistensi tinggi (kasus Indonesia dan Vietnam).

Pertanyaan yang pertama itu akan dijawab secara hipotetis sebagai berikut. Pada kasus yang terjadi di Malaysia, Singapura, dan Brunei, resistensi yang minimal terhadap penjajah ditunjukkan oleh tingkat akseptabilitas terhadap nilai- 
nilai peradaban. Bangsa-bangsa ini bersikap lebih adaptif dan akomodatif terhadap nilai-nilai peradaban eks penjajah mereka, memeliharanya dan atau sekurang-kurangnya membiarkan nilainilai itu berkembang. Sikap ini menguatkan sustainabilitas garis kontinum peradaban yang telah terbangun sejak dimulainya domain penjajahan pada bangsa-bangsa itu. Dengan perkataan lain, proses peradaban berjalan secara evolutif tanpa ada gangguan serius pada peradaban yang telah eksis sebelumnya. Pada bangsabangsa dengan tipologi ini akan kita dapatkan ciri-ciri kemiripan tertentu dengan ciri-ciri dari identitas diri bangsa penjajah mereka. Kita akan temui fakta bahwa pada bangsa-bangsa ini ditemukan mentalitas yang lebih mampu menegakkan disiplin, lebih mampu menegakkan dan mentaati peraturan, lebih mampu memahami hak dan kewajiban. Oleh sebab itu, wajar kemudian jika bangsa-bangsa ini terbukti lebih cenderung minimal dalam melakukan penyimpangan ketertiban hukum. Lebih minimal berbuat korupsi dan kolusi serta lain-lain perilaku anomali (kalimat ini kiranya cukup memadai untuk menghindari penggunaan terma clean nation atau clean government atau terma sejenisnya yang tidak akan pernah ada dalam bentuk supra idealnya dalam realitas sejarah). Pertanyaan yang kedua di atas akan dijawab dalam uraian lebih komprehensif di bawah ini.

\section{Pertumbuhan Peradaban yang Involutif}

Ciri-ciri identitas diri bangsabangsa yang disebutkan contohnya di atas, hampir-hampir tidak mudah ditemui pada bangsa Indonesia. Bahkan, sebaliknya yang didapati adalah ciri-ciri yang memprihatinkan. Proses peradaban tidak pada garis kontinum dan sifatnya juga tidak evolutif. Adalah Alexander Goldenweiser yang mengenalkan konsep involusi(involution) yang kemudian pernah popular karena dipinjam oleh Clliford Geertz untuk menjelaskan tentang involusi pertanian di Pulau Jawa (Rahman,2007; Rahman dan Yuswadi 2005). Goldenweiser melukiskan pola kebudayaan yang sesudah mencapai bentuk yang pasti, tidak berhasil menstabilisasinya atau mengubahnya menjadi satu pola baru, tetapi terus bertumbuh dan berkembang ke dalam sehingga menjadi pola yang rumit. Dicontohkan oleh Goldenweiser, seni dekoratif pada suku Maori yang dikenal karena kerumitannya, ketelitian pada garisgaris kecil dan sangat sesak dengan bentuk-bentuk yang dihiasi dengan berbagai dekorasi. Akan tetapi, jika dianalisis lebih jauh, ternyata unsur-unsur satuan pola itu hanya sedikit saja jumlahnya; bahkan dalam beberapa contoh, jelas bahwa pola yang rumit dan kompleks itu ternyata ditimbulkan oleh terbentuknya pengulangan-pengulangan 
susunan ruang dari satuan pola yang bersangkutan yang tak terkait secara sistemik.

Apa yang dilihat dalam dekorasi itu adalah pola yang hanya ditambalsulamkan saja. Pola itu tidak menghendaki digunakannya satuan-satuan lainnya, tetapi tidak menentang penggarapan di dalam satuan itu sendiri. Tidak dapat dihindari lagi, hasilnya adalah kerumitan dan kompleksitas yang makin lama makin menggila. Oleh Goldenweiser pola ini disebut sebagai keanekaragaman dalam keragaman, keahlian seni dalam monotoni. Menurut Clifford Geertz, ciriciri umum involusi yang dikemukakan oleh Goldenweiser untuk fenomena estetika itu juga merupakan ciri khas dari perkembangan sawah padi di Jawa pada kira-kira setelah pertengahan abad ke sembilan belas, antara lain: keuletan pola dasar yang meningkat; penggarapan intern yang begitu teliti dan penuh dengan pernak pernik; penjelimetan teknis dan budaya; dan keahlian teknis yang tiada habisnya. Sifat dari periode Gotik akhir (late Gotic period) di lahan pertanian ini makin lama makin meresapi seluruh ekonomi pedesaan: sistem hak milik makin rumit; hubungan sewa menyewa lahan makin ruwet, dan pengaturan kerja semakin kompleks. Semuanya itu adalah suatu upaya untuk menyediakan satu relung bagi setiap orang dalam keseluruhan sistem, betapapun kecilnya relung itu.
Di kala se bidang sawah secara rasional hanya mampu menghidupi secara layak bagi lima anggota keluarga, tetapi harus 'diisi' sebanyak yang mungkin,karena tidak ada lagi jalan keluar, selain mereka terpaksa 'bermain nasib' di satu relung yang tersedia itu. Kreatifitas memang bertumbuh, tetapi sayangnya dalam bentuk reaktifitas yang bergerak ke dalam, sentripetal, bergulung-gulung dan bergumpal bagai benang kusut masut tidak karuan. Masing-masing orang akan berpikir untuk mempertahankan posisinya yang semakin terjepit dalam relung sempit itu tanpa ada daya cipta karena ketidakberdayaan. Inilah suatu bentuk reaktifitas defensif yang hanya untuk bertahan hidup dari takdir kepunahan.

Tulisan ini mengapresiasi Alexander Goldenweiser dan Clliford Geertz yang telah dengan brilian menggunakan konsep involusi dalam konteks estetika dan dalam konteks kemelut di lahan sawah padi. Untuk memudahkan analisis tentang proses peradaban bangsa Indonesia, izinkan penulis meminjam konsep ini juga untuk menerangkan 'kemelut' yang sama yang terjadi di batang tubuh bangsa ini. Mungkin saja dalam analisis makro, bobotnya tidak sepadan, tetapi yang diperlukan di sini adalah perspektif analogisnya. Tentu saja proses pertumbuhan arsitektur Gotik yang spesifik tidak dapat memadani proses 
pertumbuhan peradaban suatu bangsa secara umum. Apalagi pengulanganpengulangan terhadap karya seni tidak mesti dirasakan sebagai apa yang dirasakan oleh penciptanya. Semakin tinggi cita rasa karya seni tersebut, semakin sedikit yang mampu menikmatinya, sebagaimana yang 'dituntut' oleh penciptanya. Di sisi yang lain, barangkali seni estetika justru diapresiasi karena kerumitan detilnya. Namun sekali lagi, analisis ini sangat berarti untuk menjelaskan proses peradaban yang sedang berlangsung di Indonesia sejak kemerdekaan sampai sekarang.

Dibandingkan dengan proses peradaban bangsa-bangsa yang mengalami gerak evolutif, maka bangsa Indonesia lebih cenderung involutif. Situasi ini tidak mudah terasakan karena dalam situasi keseharian terkesan tidak ada yang aneh. Kegiatan hari demi hari berproses seperi biasanya. Bahkan, yang dulunya luar biasa pun lama kelamaan akan terasa menjadi biasa. Yang dulunya dipandang 'haram' lama kelamaan akan menjadi 'halal' (habitually learning). Perwujudan sistem atau struktur sosial pun mengalami proses serupa demikian itu. Lebih parah lagi jika sistem berpikir juga mengalami involusi karena sistem atau struktur sosial sangat dipengaruhi oleh sistem berpikir anak bangsa ini. Teori strukturasi (structuration theory) yang dikemukakan oleh Anthony
Giddens (1984) bisa dipinjam untuk menjelaskan analisis ini.

$$
\text { Menurut Giddens, terdapat }
$$
hubungan ketergantungan timbal balik (mutual dependency) antara agensi (aktor) sosial dan struktur (sistem) sosialnya. Sang agensi atau aktor sosial sehari-harinya secara intens terlibat dalam memproduksi tindakan (production of action) yang lahir dari sistem berpikir mereka. Sebaliknya pula, struktur (sistem) sosial akan menghasilkan means and resources sebagai outcomes dari tindakan-tindakan yang dilakukan oleh para agensi tersebut. Jadi, antara agensi dan struktur atau antara aktor dan sistem terjadi diskursus yang terus menerus dalam suatu pergulatan tanpa henti. Di sinilah titik krusialnya, karena sekali proses strukturasi ini berputar, maka proses yang 'baik' akan menciptakan hasil yang 'baik'. Sebaliknya proses yang 'buruk' akan menciptakan hasil yang 'buruk' pula. Dalam bahasa teori ini: agensi atau aktor yang buruk akan menciptakan struktur atau sistem yang buruk, sebaliknya struktur atau sistem yang buruk itu tadi seterusnya akan menciptakan agensi atau aktor yang buruk. Demikian terjadi terus menerus sehingga menjadi suatu sistem makro yang buruk dan kompleks. Sesuatu yang lebih parah terjadi di kala kebanyakan agensi atau aktor itu sadar akan apa yang mereka lakukan itu buruk, tetapi tetap mereka lakukan juga, sebagaimana dikatakan 
Giddens (1984): "All human beings are knowledgable agents. That is to say, all social actors know a great deal about the conditions and consequences of what they do in their day to day lives".

Secara teoretis betapa berbahayanya bila suatu bangsa terlanjur berada dalam pusaran proses peradaban yang involutif. Peristiwa revolusi kemerdekaan 1945 merupakan 'titik sekarat' pemutusan rantai peradaban Eropa di Nusantara. Bangsa Indonesia mengalami kemelut pascakemerdekaan dalam belitan proses involusi peradaban baru yang sedang dibangun. Secara beringsut bangsa ini bergerak maju dengan cara membangun fundasi nilai baru peradaban untuk menggantikan struktur sosial yang ratusan tahun dalam tatanan struktur peradaban Eropa (yang sebenarnya pula belum matang dan belum stabil). Pada momenmomen tertentu sepanjang era pascakemerdekaan itu, terlihat berbagai momen pemutusan rantai peradaban yang ingin dibangun itu bermunculan satu per satu. Beberapa di antaranya adalah Peristiwa Madiun, Gerakan di Aceh, Dewan Banteng dan Dewan Garuda di Sumteng, Dewan Gajah di Sumut, dan PRRI/Permesta di Sumatera pada umumnya. Semua yang disebutkan itu adalah sebagai beberapa momen sosial politik yang terlepas dari kesadaran para pelakunya tentang implikasi terhadap pemutusan rantai peradaban yang sedang terbangun. Ini adalah peristiwa politik yang terlepas dari kesadaran intelektual para pelakunya tentang dampak yang akan terjadi, yakni proses peradaban bangsa Indonesia yang rumit dan involutif. Tanpa disadari benang kusut itu mulai terajut hingga kini.

Pemerintahan Soekarno yang dipenuhi dengan momen-momen sosial politik demikian itu pada akhirnya disudahi melalui gerakan revolusi anti rezim di tahun 1966. Kembali lagi proses peradaban bangsa ini diputuskan rantainya, dan ini adalah 'titik sekarat' yang kedua setelah revolusi kemerdekaan 1945. Rezim baru di bawah pemerintahan Soeharto menerapkan kursivitas politik yang keras dan dengan gaya yang berbeda, sebagai respon yang sebenarnya rasional terhadap situasi pemerintahan sebelumnya. Stabilitas politik tercapai dan mendorong pembangunan ekonomi yang lebih baik. Namun, karena kursivitas politik tidak linear dengan demokrasi dan keterbukaan, maka singkat kata di awal-awal 1998, kembali lagi peradaban bangsa jatuh ke titik nadirnya, dan ini adalah 'titik sekarat' yang ketiga. Kalau orang bertanya semuanya ini salah siapa? Sulit menjawabnya secara substansial, kecuali jawaban politik mikro. Namun, ini hanyalah masalah cerdas atau tidak cerdas para petinggi dan kaum cerdik pandai mengelola bangsa dengan benar. Pepatah Melayu mengatakan bahwa orang buta 
tidak akan kehilangan tongkat dua kali. Ini hanya pepatah untuk menyindir, karena ternyata banyak juga orang buta yang kehilangan tongkatnya berkali-kali. Bangsa ini belumlah renta, apalagi pikun dan buta. Ironisnya pula, orang pintar di negeri ini bergerbong-gerbong banyaknya.

\section{Menegakkan Peradaban yang Evolutif}

Melalui berbagai peristiwa sejarah yang demikian parah, dan dengan berkalikali mengalami 'titik sekarat', peradaban bangsa secara beringsut berupaya melepaskan diri dari kusut masut proses involusi yang tengah berlangsung. Dicemaskan dalam proses ini, apakah para pemimpin bangsa benar-benar sadar dan memahami sebab musabab kemelut peradaban ini secara substantive? Untuk mengurai benang yang kusut orang harus tahu betul mana ujung mana pangkalnya. Kalau sudah tahu ujungnya barulah benang diurai dengan teknik yang benar, dan dengan kesabaran yang tinggi. Kerapkali orang hilang kesabarannya dan dengan gampangnya memotong benang di sanasini.

Proses penegakan peradaban bangsa yang evolutif harus dilakukan dengan benar. Pertama, semua elemen bangsa harus memahami bahwa kemelut yang sedang berlangsung ini adalah disebabkan oleh sering terjadinya pemutusan rantai peradaban melalui berbagai revolusi besar dan kecil. Dengan memahami ini, semua pihak diharapkan mampu menahan diri. Khususnya kepada para pemimpin pergerakan politik, baik partai politik maupun organisasi massa sosial harus menyadari bahwa dengan sedikit pergerakan yang keliru akan sangat mudah memancing masyarakat luas untuk bergerak tanpa kontrol. Kedua, Pemerintah harus melakukan tindakan yang tidak sekedar persuasif. Sistem aturan dan pelaksanaan aturan yang lebih represif justru dianjurkan dalam situasi tertentu. Jangan khawatir bahwa aturan dan tindakan yang lebih represif akan dituduh kembali ke rezim Orde Baru, karena tuduhan yang demikian itu hanya kesan yang tidak nyata, wujud dari sisa emosi politik yang irasional. Semuanya tergantung bagaimana para pemimpin negeri menjelaskannya. Ketiga, meskipun demokrasi merupakan pilihan yang tepat dan sangat dibutuhkan di negeri ini, perlu pula menyadari bahwa democracy is not a panacea. Demokrasi ternyata tidaklah tunggal, utuh, fixed. Ia juga memberi ruang yang sangat fleksibel untuk berwarnawarni. Setiap bangsa punya hak mutlak untuk menerapkan, bahkan menciptakan demokrasi yang berwarna apa. Putih atau hitam, atau variasi gabungan berbagai warna. Sistem sosial budaya bangsa menjadi dasar kuat pembentukan demokrasi suatu bangsa akan berwarna 
apa. Sebagaimana para pendahulu bangsa ini telah menciptakan Pancasila sebagai dasar Negara yang berlaku hingga kini, maka warna demokrasi itupun sebenarnya telah pula dipilih. Penulis mengkhawatirkan bahwa pandangan kita tentang demokrasi belum sepenuhnya cerdas. Tidak secerdas para pendahulu kita.

\section{DAFTAR PUSTAKA}

Ankerl, Guy (2000). Coexisting Contemporary Civilizations: ArabMoslem< Bhatari, Chinese, and Western. Inerpress, Geneva.

Brinton, Crane (et.al) (1984). A History of Civilization: Prehistory to $1718.6^{\text {th }}$ edition, Englewood Cliffs, NJ: Prentice Hall.

Chrisholm, Jane and Anne Millard (1996). Early Civilization. London: Usborne.

David Gauntlet (2001) http://www.theory.org.uk. Resources: Anthony Giddens

Fernandez-Armesto, Felipe (2000). Civilizations. London: Mc Millan.

Giddens, Anthony (1984). The constitution of Society: Outline of the theory of Structuration. Cambridge: Polity Press.

Giddens, Anthony (1993). New Rules of Sociological Method: A Positive Critique of Interpretive Sociologies. 2nd ed. Cambridge: Polity Press.

Giddens, Anthony (1990). The consequences of Modernity. Cambridge: Polity Press.

Giddens, Anthony (1989). Social Theories of Modern Societies. Cambridge: Polity Press.
Giddens, Anthony (1991). Modernity and Self Identity: Self and Society in the Late Modern Age. Stanford: University Press.

Nuri Yurdusev, A. (2003). International Relations and the Philosophy of History: A Civilization Approach. London: Mc Millan.

Rahman, Bustami (2007). Kemelut Lahan Pertanian di Jawa: Evolusi versus Involusi. Pangkalpinang: UBB Press.

Rahman, Bustami dan Hary Yuswadi (2005). Sistem Sosial Budaya Indonesia. Jember: Kompyawisda.

www.infoplease.com'ipa/AO108144.html (2008). History of Vietnam.

www.infoplease.com/ipa/AO107751.html (2008). History of Malaysia.

www.wikipedia.org/wiki (2008). History of Thailand.

www.wikipedia.org/wiki (2008). History of Brunei Darussalam.

www.wikipedia.org/wiki (2008). History of Singapore. 